\title{
SWOT analysis of handloom weaving units of Assam
}

\author{
Rickey Rani Boruah and Momita Konwar
}

Received: 29.09.2020; Revised: 05.11.2020; Accepted: 25.11.2020

See end of the paper for authors' affiliations Rickey Rani Boruah Department of Textiles and Apparel Designing, College of Community Science Assam Agricultural University, Jorhat (Assam) India

Email : rickey_boruah@ rediffmail.com
ABSTRACT : Handloom industry in India is an ancient cottage industry with a decentralized set up. Handloom sector plays a very important role in the country's economy. Assam is a state situated in the northeast of India and is located just below the eastern Himalayan foothills. Handloom industry is the most important industry in Assam having a glorious past. It is closely associated with art and culture of the society. It is the largest cottage industry next to agriculture and plays a key role in the socio- economic life of the people. Inspite of considerable efforts made to rehabilitate it; handloom weaving units continue to be in the grip of problems. Therefore the purpose of this study is to familiarize with the strength, weakness, opportunities and threat of Handloom weaving units of Assam.

KEY WORDS: Handloom industry, Strength, Weakness, Opportunities, Threat

- HOW TO CITE THIS PAPER : Boruah, Rickey Rani and Konwar, Momita (2020). SWOT analysis of handloom weaving units of Assam. Asian J. Home Sci., 15 (2) : 345-347, DOI: 10.15740/HAS/AJHS/15.2/ 345-347. Copyright@ 2020: Hind Agri-Horticultural Society. 